\title{
Bedre influensavaksine hos eldre?
}

\author{
Høydose influensavaksine kan bedre beskyttelsen mot influensa \\ hos eldre.
}

Svekket immunforsvar hos eldre gir økt risiko for komplikasjoner ved influensa og redusert effekt av influensavaksine. Kan effekten økes ved å øke antigenmengden i vaksinen?

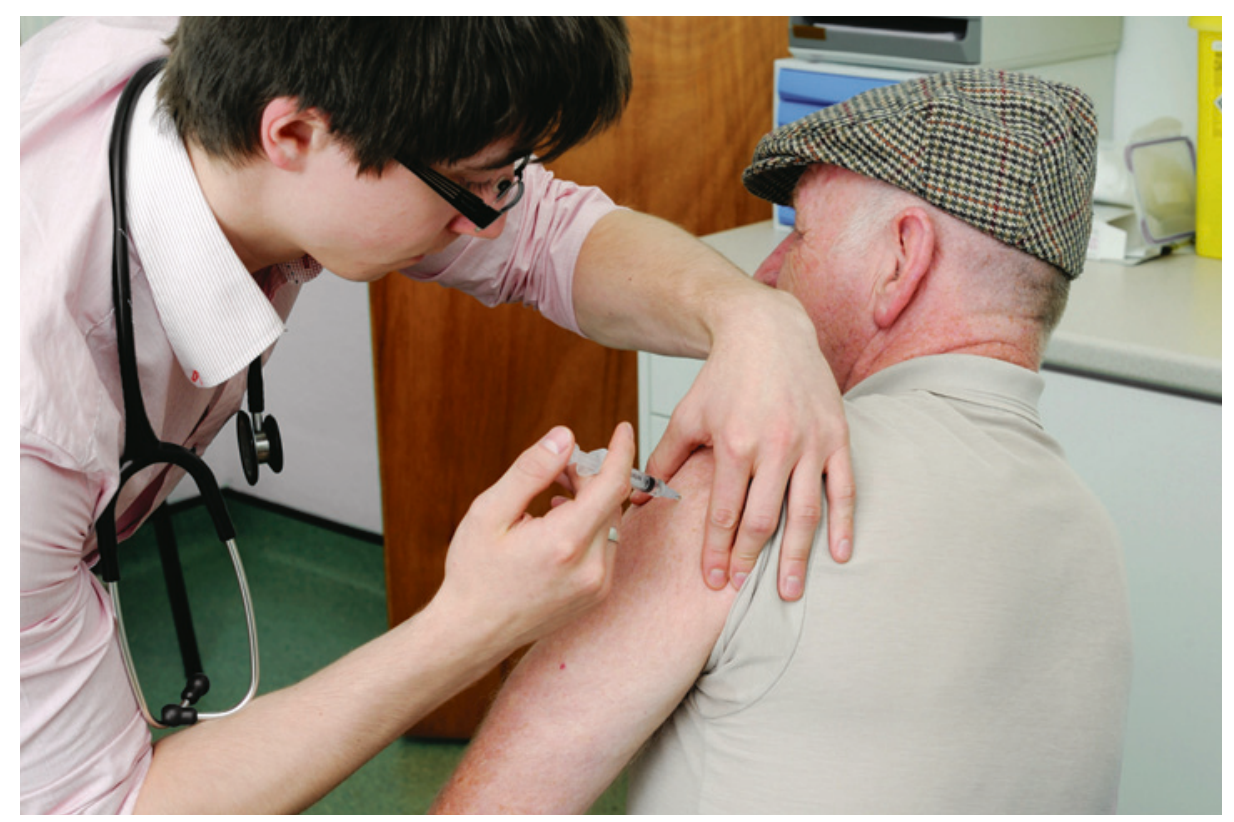

Illustrasjonsfoto: Science photo/NTB scanpix
I en nylig publisert studie, sponset av vaksineprodusenten Sanofi Pasteur, ble over 30000 personer over 65 år randomisert til enten standard- eller høydosevaksine. I løpet av studieperioden fikk 529 personer influ-

ensasykdom, definert på grunnlag av kliniske kriterier og laboratoriefunn. Av disse hadde 301 fått standardvaksine og 228 høydosevaksine, dvs. en relativ risikoreduksjon på $24,2 \%$ $(95 \%$ KI 9,7-36,5) i favør av høydose. Estimert bestefallseffekt av høydosevaksinen var $62 \%$, mot $50 \%$ for standardvaksinen.

- En svakhet ved denne studien er at samlet estimat for alle som hadde laboratoriebekreftet influensa ikke er oppgitt, sier Ellen Furuseth, som er lege ved Avdeling for vaksine, Nasjonalt folkehelseinstitutt. - Den relative risikoreduksjonen gjaldt dem som ble identifisert ut fra ett av tre kliniske kriteriesett, og for de to andre gruppene var den relative effekten mindre, påpeker hun.

- I Norge er vaksinedekningen hos personer over 65 år så lav som $40 \%$. Sannsynligvis vil det være mer å hente ved å øke dekningsgraden av standardvaksine enn å gå over til høydosevaksine. Vi må finne nye og bedre måter å forebygge influensa hos eldre på, og denne studien er ett bidrag til den samlede kunnskap på dette området, sier Furuseth.

\section{Lise Mørkved Helsingen}

Tidsskriftet

\section{Litteratur}

1. DiazGranados CA, Dunning AJ, Kimmel M et al. Efficacy of high-dose versus standard-dose influenza vaccine in older adults. N Engl J Med 2014; 371: $635-45$.

\section{Regulerende T-celler i behandling av autoimmunitet}

\author{
Induksjon av regulatoriske T-cel- \\ ler gir toleranse for autoimmun \\ encefalomyelitt og diabetes hos \\ mus.
}

Den ideelle behandlingen av autoimmune sykdommer vil være å skape toleranse overfor autoantigener, mens immunresponsen mot andre antigener forblir intakt. En amerikansk forskergruppe har presentert hvordan dette kan gjøres hos mus (1).

Forskerne brukte mus med autoimmun encefalomyelitt eller diabetes (EAE- og NODmus). Først induserte de apoptose av immunceller ved hjelp av systemisk bestråling eller antistoffer, deretter ble de kjente autoantigenene injisert. De apoptotiske immuncellene stimulerte fagocytter i sentralnervesystemet og bukspyttkjertelen til å utskille et cytokin (TGF- $\beta$ ). Under påvirkning av dette cytokinet induserte autoantigenene naive $\mathrm{CD}^{+}$ T-lymfocytter til å bli regulerende T-celler $\left(\mathrm{Foxp}^{+} \mathrm{T}_{\text {reg }}\right.$ ). De regulerende T-cellene forebygde danningen av skadelige T-celler eller hemmet etablerte skadelige reaksjoner ved de to sykdommene. Immunresponsen mot tuberkelbasiller ble ikke redusert. Etter bestråling måtte fagocyttpopulasjonen bygges opp med injeksjon av miltmakrofager. Dette var ikke nødvendig etter antistoffbehandling (anti-CD20 og anti-CD8).

- Dette er en interessant studie som viser at det er mulig å reetablere toleranse ved autoimmune sykdommer, sier professor Bjarne Bogen ved K.G. Jebsen-senter for forskning på influensavaksiner, Universitetet i Oslo. - Behandling av autoimmune sykdommer med immundempende medisiner har betydelige bivirkninger, og det er derfor behov for å utvikle andre behandlingsprinsipper. T-regulatoriske celler er en relativt nyoppdaget subpopulasjon av T-celler, som kan hemme andre skadelige T-celler. Virkningsmekanismene er i stor grad ukjent, og vi har liten kunnskap om hvordan disse cellene kan induseres i pasienter. Veien frem mot human applikasjon er nok lang, sier Bogen.

\section{Haakon B. Benestad \\ Universitetet i Oslo}

\section{Litteratur}

1. Kasagi S, Zhang P, Che L et al. In vivo-generated antigen-specific regulatory $T$ cells treat autoimmunity without compromising antibacterial immune response. Sci Transl Med 2014; 6: 241 ra78. 